\title{
Review Article \\ Genetic Divergence, Implication of Diversity, and Conservation of Silkworm, Bombyx mori
}

\author{
Bharat Bhusan Bindroo and Shunmugam Manthira Moorthy \\ Central Sericultural Research and Training Institute, Srirampura, Mysore, Karnataka 570 008, India \\ Correspondence should be addressed to Shunmugam Manthira Moorthy; moorthysm68@gmail.com
}

Received 29 December 2013; Accepted 22 April 2014; Published 13 May 2014

Academic Editor: Alexandre Sebbenn

Copyright (C) 2014 B. B. Bindroo and S. Manthira Moorthy. This is an open access article distributed under the Creative Commons Attribution License, which permits unrestricted use, distribution, and reproduction in any medium, provided the original work is properly cited.

\begin{abstract}
Genetic diversity is critical to success in any crop breeding and it provides information about the quantum of genetic divergence and serves a platform for specific breeding objectives. It is one of the three forms of biodiversity recognized by the World Conservation Union (IUCN) as deserving conservation. Silkworm Bombyx mori, an economically important insect, reported to be domesticated over 5000 years ago by human to meet his requirements. Genetic diversity is a particular concern because greater genetic uniformity in silkworm can increase vulnerability to pests and diseases. Hence, maintenance of genetic diversity is a fundamental component in long-term management strategies for genetic improvement of silkworm which is cultivated by millions of people around the worlds for its lusture silk. In this paper genetic diversity studies carried out in silkworm using divergent methods (quantitative traits and biochemical and molecular markers) and present level of diversity and factors responsible for loss of diversity are discussed.
\end{abstract}

\section{Introduction}

Sericulture is a unique field of agriculture, because silkworms are reared on an extensive scale in rearing houses and their silk cocoons are utilized as fine material for clothing. Like agriculture, sericulture also requires a continuous flow of productive silkworm breeds and host plant varieties to meet the ever-changing demand of people involved in the industry besides the consumer sector. To meet all these requirements, the breeder needs very wide and inexhaustible genetic resources to meet the ever-changing demands from various sectors. Considering the great economic importance of Bombyx mori, silk producing countries, such as China, Japan, India, Russia, Korea, Bulgaria, and Iran, have collected number of silkworm breeds suitable for a wide range of agroclimatic conditions. More than 4000 strains are maintained in the germplasm of B. mori and 46 institutes are involving silkworm genetic resources maintenance, which includes univoltine, bivoltine, and polyvoltine strains. These different genotypes display large differences in their qualitative and quantitative traits that ultimately control silk yield. It was estimated that silkworm genome consists of about $4.8^{\prime} 108 \mathrm{bp}$; its genetic information volume is about one-sixth of human being. There are over 450 morphological, physiological, and biochemical characters recorded at present, among them 300 (including multiallele) had been located on 27 groups of the total 28 chromosomes [1]. Apart from a rich biodiversity of geographical races, there are also a large number of mutants for a variety of characters present in B. mori [2].

\section{Genetic Divergence in Silkworm}

Study on genetic diversity is critical to success in any crop breeding and it provides information about the quantum of genetic divergence and serves as a platform for specific breeding objectives [3]. Genetic diversity is usually thought of as the amount of genetic variability among individuals of a variety or population of a species [4]. It results from the many genetic differences between individuals and may be manifest in differences in DNA sequence, in biochemical characteristics (e.g., in protein structure or isoenzyme properties), in physiological properties (e.g., abiotic stress 
resistance or growth rate), or in morphological characters [5]. Genetic diversity has been conventionally estimated on the basis of different biometrical techniques (Metroglyph, $D^{2}$ divergence analysis, and principal component analysis) such as phenotypic diversity index $(H)$, or coefficient of parentage utilizing morphological, economical, and biochemical data [6-9].

The genetic diversity of $B$. mori is derived from hybridization of different geographical origins, mainly the Japanese, Chinese, European, and Indian strains, which have distinct traits. Among these four geographical strains, silkworm of temperate origin produces a higher quantity of good, finer, stronger silk fiber, whereas the tropical strains are hardy, tolerant to pathogen load, and resistant to diseases. However, the tropical strains produce low amounts of silk, which is coarser and weaker [10]. To help the breeders in the process to identify the parents that nick better, several methods of divergence analysis based on quantitative traits have been proposed to suit various objectives. As most of the desirable characters in silkworm are quantitative nature, multivariate statistical methods have been employed to measure the genetic diversity among the stocks. Among them, $D^{2}$ analysis of Mahalanobis [10] using Tocher's optimization method [11] occupies a unique place and an efficient method to gauge the extent of diversity among genotypes, which quantify the difference among several quantitative traits. It is being used by most of the workers and has been found as an extremely useful tool for estimating genetic divergence in the silkworm [12-16]. Table 1 summarizes genetic divergence study carried out by several workers in silkworm. Using this method, silkworm genotypes were formed into different clusters indicating presence of distinct divergence among the genotypes. Though divergence reported to exist among genotypes and mixed trend of clustering observed. Jolly et al. [13] subjected forty-nine silkworm breeds for this analysis and reported that these breeds were found to form three distinct clusters indicating the presence of distinct diversity among the breeds. Subba Rao et al. [14] and Govindan et al. [15] reported that breeds derived from the same parents were included in different clusters showing variation among the breeds derived from the same source. On the other hand, the breeds derived from the same source were included in the same cluster showing close affinity between advanced sister lines $[12,14,15]$ and those of differing genetic background occupied in single cluster indicated uniformity in selection procedures [12]. However, genotypes of temperate and tropical origin formed into separate clusters indicating environmental influence on the expression of characters [17]. Though theoretically geographical diversity is important factor, it is not the whole determining factor for genetic divergence $[18,19]$. All these studies were aimed to identify suitable parents for breeding programme and recommended to cross the genotypes from different clusters [20-22] for yield improvement. Though many characters in silkworm are subjected for divergence study, characters, namely, fecundity larval weight, single cocoon weight, cocoon shell weight, and filament length only, contributed about $97 \%$ to the total genetic divergence $[12,13,16,23,24]$.

\section{Diversity in Silkworm}

Genetic diversity is most often characterized using data that depict variation in either discrete allelic states or continuously distributed (i.e., quantitative) characters, which lead to different possible metrics of genetic diversity [25]. Genetic diversity can be assessed among different accessions/individuals within the same species (intraspecific), among species (interspecific). and between genus and families [26]. It plays an important role in any breeding either to exploit heterosis or to generate productive recombinants. The choice of parents is of paramount importance in any kind of breeding programme; hence, the knowledge of genetic diversity and relatedness in the germplasm is a prerequisite for crop improvement programmes. Genetic diversity is also an essential aspect in conservation biology because a fundamental concept of natural selection states that the rate of evolutionary change in a population is proportional to the amount of genetic diversity present in it [27]. Decreasing genetic diversity increases the extinction risk of populations due to a decline in fitness. Genetic diversity also has the potential to affect a wide range of population, community, and ecosystem processes both directly and indirectly. However, these effects are contingent upon genetic diversity being related to the magnitude of variation in phenotypic traits [28].

In general, cocoon colour and cocoon shape, larval, marking, and quantitative traits have been used for differentiation of silkworm genotypes and, based on that, parents are being selected. However, recent advent of different molecular techniques led breeders to estimate genetic diversity on the basis of data generated by different molecular markers, which provided a means of rapid analysis of germplasm and estimates of genetic diversity, which were often found to corroborate phenotypic data. These molecular markers are broadly categorized as biochemical and molecular markers.

3.1. Biochemical Markers. Application of isoenzymes and other molecular markers helps to estimate genetic diversity much more accurately than that of morphological traits. Electrophoresis identifies variation (alleles) at loci that codes for enzymes (usually termed isozymes or allozymes). One advantage of allozyme loci is that they are codominant and heterozygotes can be scored directly. Understanding the genetic constitution of an individual in the population of races and allelic variations through isozyme studies is known to reflect the differential catalytic ability of allelic genes and their significant role in the adaptive strategy of the genotypes [29].

The diversity study carried out in silkworm through protein profiles, enzymes, and isozymes are summarized in Table 2. Isozymes like esterase, acid phosphatase, alkaline phosphatase, amylase, phosphoglucomutase, aspartate aminotransferase, malate dehydrogenase, glucose 6 phosphate dehydrogenase, and carbonic anhydrase have been used by various authors to study diversity in silkworm genotypes [30-43]. Among the different isoenzymes analyzed, esterase was most preferred because of its diverse substrate specificity and polymorphic expression followed by acid phosphatase [36, 37, 44]. Eguchi et al. [32] found four 
TABLE 1: Genetic divergence study reported in silkworm.

\begin{tabular}{|c|c|c|c|c|}
\hline $\begin{array}{l}\text { SL } \\
\text { number }\end{array}$ & $\begin{array}{l}\text { Reference } \\
\text { number }\end{array}$ & $\begin{array}{l}\text { Number of } \\
\text { genotypes used } \\
\text { and clusters } \\
\text { formed }\end{array}$ & $\begin{array}{l}\text { Measures of genetic } \\
\text { diversity }\end{array}$ & Conclusion \\
\hline 1 & {$[89]$} & 49 and 3 & $\begin{array}{l}\text { Mahalanobis (1936) and } \\
\text { Tocher (1956) }\end{array}$ & $\begin{array}{l}\text { (1) Presence of distinct diversity. (2) Breeds derived from the } \\
\text { same parents were included in different clusters. (3) Breeds } \\
\text { derived from the same source were included in the same cluster. }\end{array}$ \\
\hline 2 & {$[23]$} & 32 and 7 & $\begin{array}{l}\text { Mahalanobis (1936) and } \\
\text { Tocher }\end{array}$ & $\begin{array}{l}\text { Geographical diversity did not contribute much to genetic } \\
\text { diversity. }\end{array}$ \\
\hline 3 & [14] & 15 and 5 & $\begin{array}{l}\text { Mahalanobis (1936) and } \\
\text { Tocher (1956) }\end{array}$ & $\begin{array}{l}\text { (1) Enough diversity present. (2) Suggested for making crosses } \\
\text { between different clusters. }\end{array}$ \\
\hline 4 & [116] & 50 and 5 & $\begin{array}{l}\text { Mahalanobis (1936) and } \\
\text { Tocher (1956) }\end{array}$ & $\begin{array}{l}\text { Cluster III was the largest, consisting of } 34 \text { strains. The clusters } \\
\text { are compared for various features influencing silk production. }\end{array}$ \\
\hline 5 & [15] & 18 and 8 & $\begin{array}{l}\text { Mahalanobis (1936) and } \\
\text { Tocher (1956) }\end{array}$ & $\begin{array}{l}\text { Breeds derived from the same ancestry were included in } \\
\text { different clusters and those of different genetic background } \\
\text { occupied a single cluster. }\end{array}$ \\
\hline 6 & {$[20]$} & 25 and 6 & $\begin{array}{l}\text { Mahalanobis (1936) and } \\
\text { Tocher (1956) }\end{array}$ & The genetically divergent parents were grouped into four classes. \\
\hline 7 & [18] & 30 and 5 & $\begin{array}{l}\text { Mahalonobis' } D^{2} \text { values } \\
\text { (Ward's minimum } \\
\text { variance) }\end{array}$ & $\begin{array}{l}\text { Geographical diversity though important is not the determining } \\
\text { factor for genetic divergence. }\end{array}$ \\
\hline 8 & {$[24]$} & 24 and 7 & $\begin{array}{l}\text { Mahalanobis (1936) and } \\
\text { Tocher }\end{array}$ & $\begin{array}{l}\text { Genotypes of temperate and tropical origin formed separate } \\
\text { clusters. }\end{array}$ \\
\hline 9 & {$[117]$} & 11 and 3 & $\begin{array}{l}\text { Mahalanobis (1936) and } \\
\text { Tocher (1956) }\end{array}$ & $\begin{array}{l}\text { The intracluster distance ranged from } 0.00 \text { to } 1689.37 \text { implying } \\
\text { the prevalence of substantial amount of intracluster diversity. }\end{array}$ \\
\hline 10 & {$[21]$} & 22 and 6 & $\begin{array}{l}\text { Mahalonobis' } D^{2} \text { values } \\
\text { (Ward's minimum } \\
\text { variance.) }\end{array}$ & $\begin{array}{l}\text { There is no relation between geographical diversity and genetic } \\
\text { diversity. }\end{array}$ \\
\hline 11 & [118] & 65 and 9 & $\begin{array}{l}\text { Mahalonobis' } D^{2} \text { values } \\
\text { (Ward's minimum } \\
\text { variance) }\end{array}$ & $\begin{array}{l}\text { Breeds in the optimum distance obtained cluster can be used in } \\
\text { the conventional silkworm breeding programme to improve silk } \\
\text { quality. }\end{array}$ \\
\hline 12 & [119] & 47 and 12 & $\begin{array}{l}\text { Mahalonobis' } D^{2} \text { values } \\
\text { (Ward's minimum } \\
\text { variance) }\end{array}$ & Geographic diversity had no association with genetic diversity. \\
\hline 13 & {$[120]$} & 51 and 2 & UPGMA & $\begin{array}{l}\text { Clusters of individuals exhibited high internal (within clusters) } \\
\text { homogeneity and high external (between clusters) } \\
\text { heterogeneity. }\end{array}$ \\
\hline 14 & {$[121]$} & 16 and 3 & $\begin{array}{l}\text { Mahalanobis (1936), } \\
\text { UPGMA }\end{array}$ & $\begin{array}{l}\text { The strains of the same origin did not group together, } \\
\text { demonstrating they can have different biological and } \\
\text { development performance. }\end{array}$ \\
\hline 15 & {$[122]$} & 8 and 5 & $\begin{array}{l}\text { Mahalanobis (1936), } \\
\text { UPGMA }\end{array}$ & $\begin{array}{l}\text { Genetic distance and not the geographic diversity is to be } \\
\text { considered while identifying parents for hybridization } \\
\text { programme. }\end{array}$ \\
\hline 16 & [16] & 21 and 7 & $\begin{array}{l}\text { Mahalanobis (1936) and } \\
\text { Tocher (1956) }\end{array}$ & $\begin{array}{l}\text { Silkworm genotypes originating from the same geographical } \\
\text { regions fell in one cluster. }\end{array}$ \\
\hline 17 & [17] & 56 and 8 & $\begin{array}{l}\text { Mahalanobis (1936) and } \\
\text { Tocher (1956) }\end{array}$ & $\begin{array}{l}\text { Silkworm genotypes originating from different geographical } \\
\text { regions fell in one cluster while those originating from a single } \\
\text { region fell in different clusters. }\end{array}$ \\
\hline 18 & {$[123]$} & 51 and 4 & $\begin{array}{l}\text { Hierarchical agglomerative } \\
\text { clustering UPGMA }\end{array}$ & $\begin{array}{l}\text { Inclusion of genotypes of the same origin in different clusters } \\
\text { clearly indicates the presence of considerable genetic diversity } \\
\text { among the populations. }\end{array}$ \\
\hline 19 & [19] & 19 and 3 & $\begin{array}{l}\text { The hierarchical cluster } \\
\text { analysis using Euclidian } \\
\text { distance }\end{array}$ & $\begin{array}{l}\text { Cluster analysis and conformity with the variability in the } \\
\text { performance of the genotypes for different traits. Geographic } \\
\text { diversity had no association with genetic diversity. }\end{array}$ \\
\hline 20 & {$[124]$} & 4 and 2 & $\begin{array}{l}\text { UPGMA method (Sokal } \\
\text { and Michener) }\end{array}$ & $\begin{array}{l}\text { The optimum level of genetic distance is necessary to obtain } \\
\text { heterosis. }\end{array}$ \\
\hline
\end{tabular}


TABLE 2: Genetic divergence study reported in silkworm using enzymes, protein, and isozymes.

\begin{tabular}{|c|c|c|c|c|}
\hline $\begin{array}{l}\text { SL } \\
\text { number }\end{array}$ & $\begin{array}{l}\text { Reference } \\
\text { number }\end{array}$ & $\begin{array}{c}\text { Number of } \\
\text { genotypes and } \\
\text { clusters }\end{array}$ & $\begin{array}{l}\text { Measures of genetic } \\
\text { diversity }\end{array}$ & Conclusion \\
\hline 1 & {$[32]$} & - & $\begin{array}{l}\text { Esterase used for } \\
\text { polymorphism }\end{array}$ & Polymorphism noticed among genotypes. \\
\hline 2 & {$[125]$} & - & $\begin{array}{l}\text { Protein profiles used for } \\
\text { genetic diversity }\end{array}$ & $\begin{array}{l}\text { Divergence arises internally after a relatively long amino } \\
\text { terminal sequence which appears to be conserved. A plausible } \\
\text { explanation for the observed genetic variability is the } \\
\text { occurrence of relatively large unequal crossing-over exchanges } \\
\text { in the repetitive domain of the fibroin gene. }\end{array}$ \\
\hline 3 & {$[126]$} & - & $\begin{array}{l}\text { Esterase used for } \\
\text { polymorphism }\end{array}$ & Polymorphism noticed among genotypes. \\
\hline 4 & {$[127]$} & & $\begin{array}{l}\text { Acid phosphatase used for } \\
\text { polymorphism }\end{array}$ & Polymorphism observed among genotypes. \\
\hline 5 & {$[128]$} & 20 & Enzymes & Rich genetic diversity among genotypes. \\
\hline 6 & [129] & 10 & $\begin{array}{l}\text { Esterase used for } \\
\text { polymorphism }\end{array}$ & Polymorphism noticed among genotypes. \\
\hline 7 & {$[36]$} & 12 and 6 & $\begin{array}{l}\text { Nei and } \mathrm{Li}(1978)[130] \text { and } \\
\text { Yeh et al. (1999) [131] }\end{array}$ & Rich genetic diversity among genotypes. \\
\hline 8 & {$[132]$} & 8 and 2 & Enzymes and UPGMA & Genetic diversity noticed among genotypes. \\
\hline 9 & {$[133]$} & & Nei and Li (1978) & $\begin{array}{l}\text { The protein profile of different breeds has indicated the } \\
\text { polymorphism and genetic diversity among silkworm breeds. }\end{array}$ \\
\hline 10 & {$[37]$} & 15 & - & Esterase exhibited polymorphism among the bivoltine breeds. \\
\hline 11 & {$[134]$} & 6 and 3 & Protein & Genetic differentiation among populations of different races. \\
\hline 12 & {$[44]$} & 12 and 2 & Nei and Li (1978) UPGMA & $\begin{array}{l}\text { The mean value of FST }(0.2224) \text { calculated on the base of the } \\
\text { established polymorphism showed that } 22.24 \% \text { of the genetic } \\
\text { variability was observed between the different strains, which } \\
\text { corresponds to the level of the interstrain genetic differentiation. }\end{array}$ \\
\hline 13 & {$[40]$} & 21 and 8 & Nei and Li (1978) UPGMA & $\begin{array}{l}\text { Genetic variations were observed and they can be identified by } \\
\text { relating with their morphology and geographical origins }\end{array}$ \\
\hline 14 & [135] & & Nei and Li (1978) UPGMA & $\begin{array}{l}\text { Protein profiles studied and presence of rich genetic diversity } \\
\text { among germplasm stocks. Different origin accessions } \\
\text { established a close relationship indicating close affinity in } \\
\text { protein pattern. }\end{array}$ \\
\hline 15 & {$[41]$} & 15 & $\begin{array}{l}\text { Esterase used for } \\
\text { polymorphism }\end{array}$ & Variation in esterase pattern was observed among genotypes. \\
\hline 16 & {$[43]$} & 10 and 2 & $\begin{array}{l}\text { Nei (1978) by UPGMA } \\
\text { dendrogram (Sneath and } \\
\text { Sokal, 1973) }\end{array}$ & $\begin{array}{l}\text { A perusal of genetic diversity within and among strains } \\
\text { indicated that } 34.72 \% \text { of the observed variation occurred among } \\
\text { strains and the rest of the variation }(65.28 \%) \text { within strains. } \\
\text { Their rich genetic diversity needs to be exploited in } \\
\text { conservation and breeding programme. }\end{array}$ \\
\hline 17 & [136] & 4 & $\begin{array}{l}\text { (Swofford and Selander, } \\
\text { 1981) }\end{array}$ & $\begin{array}{l}\text { The lower degree of observed heterozygosity and the higher } \\
\text { degree of homozygotes proved the inbreeding effect. }\end{array}$ \\
\hline 18 & {$[42]$} & 15 and 3 & Nei (1978) and UPGMA & $\begin{array}{l}\text { Japanese and Chinese strains could not be totally separated by } \\
\text { the isoenzyme system analysis. The results indicate that, in spite } \\
\text { of the genetic distance and differentiation among the lineages, } \\
\text { they cannot be separate just with the isozymes alleles. The high } \\
\text { FST value (0.6128) allows the conclusion that the lineages are } \\
\text { differentiated. }\end{array}$ \\
\hline
\end{tabular}

fundamental types of esterase and about $70 \%$ of the Japanese, Chinese, and European races investigated belong to A type and $20 \%$ to 0 type, while B type was found only in Chinese races. Yoshitake et al. [45] analyzed polymorphism pattern of esterase and acid phosphates in 300 strains of silkworm and concluded that distribution of acid phosphatase and esterase was similar in European and Japanese strains and there was resemblance between Chinese and European strains. A higher degree of interstrain variability was reported on the acid phosphatase [43, 44] and esterase [36, 37, 41, 42]. Acid phosphatase is also found to be a suitable marker for analyzing the inter- and intrastrain diversity and the strain 
differentiation [44]. Isozyme analysis in different silkworm genotypes by different authors indicated rich genetic diversity between the genotypes and results were mainly used to separate populations and strains in order to use them in selection programs.

3.2. Molecular Markers. Molecular diversity studies assess all levels of genetic structure and species specific complex components [46]. The detection and exploitation of naturally occurring DNA sequence polymorphisms have wide potential applications in animal and plant improvement programmes as a means for varietal and parentage identification facilitate genetic diversity and relatedness estimations in germplasm [47]. The results obtained from different molecular markers may themselves be quite different from those obtained by using biochemical markers such as isozymes or morphological characters. The molecular markers, namely, RAPD, RFLP, ISSR, and SSR, have been effectively utilized in analyzing the genetic diversity and phylogenetic relatedness in the domesticated silkworm Bombyx mori [48-56]. Details of diversity study carried out in silkworm through molecular markers are summarized in Table 3. RAPD based dendrogram resulted in a clear separation of two groups, one comprising of diapausing and other comprising of nondiapausing genotypes [49, 57-60]. Among the diapausing genotypes, all the "Chinese type" genotypes which spin oval cocoons grouped separately, while the "Japanese type" genotypes which spin peanut shaped cocoons were found in another group. Further genotypes, which share the same geographical origin, were grouped in the same cluster [57, 61]. SSR and mtDNA markers analysis revealed considerable genetic diversity among the nondiapausing silkworm genotypes that were developed in India, China, and Bangladesh [62]. The dendrogram constructed analysing RFLP markers revealed two distinct groups as Khorasan native (Iran) and Japanese commercial lines. The distinct clustering of these two sets of strains and lines reflects differences of the geographical origin and morphological, qualitative, and quantitative traits associated with them [54]. Kim et al. [63] made phylogenetic analysis using the individual or the nine concatenated intronic sequences which showed no clustering on the basis of known strain characteristic such as voltinism, moultinism, egg colour, blood colour, cocoon colour, or cocoon shape. Furthermore, the tree obtained by them using the nine concatenated intronic sequences comprising 5,897 bp including indels resulted in a similar conclusion. However, Tunca et al. [64] stated moderately low level of diversity among genotypes studied. Supporting this argument recently, Jagadeesh Kumar [65] reported the low level of genetic distance between the breeds on the basis of gene frequency evidenced by the boot strap values in the constructed dendrogram with the help of molecular markers.

On the whole, the diversity study conducted using phenotypic characters and molecular markers had reported adequate genetic variation between genotypes. But these differentiations mostly based on voltinism and geographical origin indicating narrow genetic base between the available genotypes.

\section{Status of Genetic Diversity in Silkworm}

Zhang et al. [51] reported that genetic distances within Japanese strains are closer than those of Chinese strains and within a strain; the individual polymorphism is significantly higher in wild silkworm than those of domesticated silkworm. According to Liu et al. [66] at the species level, Antheraea pernyi and Bombyx mori showed high levels of genetic diversity, whereas Samia cynthia ricini showed low level of genetic diversity. However, at the strains level, Antheraea perny $i$ had relatively the highest genetic diversity and $B$. mori had the lowest genetic diversity. Analysis of molecular variance (ANOVA) suggested that $60 \%$ and $72 \%$ of genetic variation resided within strains in Antheraea pernyi and Samia cynthia ricini, respectively, whereas only $16 \%$ of genetic variation occurred within strains in B. mori. Similarly, genetic variation was measured using the population size scaled mutation rate which was significantly smaller in domesticated strains (0.011), when compared to the wild strains (0.013) of B. mori. The rate of heterozygosity in domesticated strains was reported to be two times lower than that in wild varieties (0.003 and 0.008, resp.). Recently, Yukuhiro et al. [67] analyzed PCR amplified carbamoyl-phosphate synthetase 2, aspartate transcarbamylase, and dihydroorotase (CAD) gene fragments from 146 Bombyx mori native strains and found extremely low levels of DNA polymorphism. CAD haplotype analysis of 42 samples of Japanese $B$. mandarina revealed four haplotypes. No common haplotype was shared between the two species and at least five base substitutions were detected. These results suggesting that low levels of gene flow between the two species. Further extremely low level of DNA polymorphism in $B$. mori compared to its wild relatives suggested that the $C A D$ gene itself or its tightly linked regions are possible targets for silkworm domestication. This information clearly indicates narrow level of genetic diversity in silkworm.

\section{Causes for Loss of Genetic Diversity}

The existence of genetic variation within a population is crucial for its ability to evolve in response to novel environmental challenges. Genetically variable populations are expected to evolve morphological, physiological, or behavioural mechanisms to cope with the novel conditions [68]. This sorting process not only results in populations that are better adapted to their local environments, but may also, at least in theory, cause a reduction in the genetic variation. Forces that affect genetic variation within populations are effective population size, mutation, genetic drift, gene flow, inbreeding depression, out breeding depression, and natural selection. In silkworm, reduction in genetic diversity might be mainly due to domestication, breeding systems, selection, genetic drift, and inbreeding. In maize, too, selection and drift due to the domestication are the principal factors that influence 
TABLE 3: Molecular diversity reported in silkworm.

\begin{tabular}{|c|c|c|c|c|}
\hline $\begin{array}{l}\text { Sl } \\
\text { number }\end{array}$ & $\begin{array}{l}\text { Reference } \\
\text { number }\end{array}$ & $\begin{array}{c}\text { Number of } \\
\text { genotypes and } \\
\text { Cluster }\end{array}$ & $\begin{array}{l}\text { Measures of } \\
\text { genetic diversity }\end{array}$ & Conclusion \\
\hline 1 & {$[48]$} & 13 and 2 & RAPD & $\begin{array}{l}\text { Silkworm genotypes were clustered into two groups, one } \\
\text { consisting of six diapausing and the other of seven } \\
\text { nondiapausing genotypes. RAPD technique could be used as a } \\
\text { powerful tool to generate genetic markers that are linked to } \\
\text { traits of interest in the silkworm. }\end{array}$ \\
\hline 2 & {$[57]$} & 13 & $\begin{array}{l}\text { RAPD and banded } \\
\text { krait minor } \\
\text { satellite DNA }\end{array}$ & $\begin{array}{l}\text { The RAPD based dendrogram resulted in a clear separation of } \\
\text { two groups, one comprising diapausing and the other } \\
\text { nondiapausing genotypes. The clustering pattern of RFLP } \\
\text { obtained was comparable to the phenogram resulting from } \\
\text { RAPD analysis. }\end{array}$ \\
\hline 3 & {$[49]$} & 5 and 3 & RAPD & $\begin{array}{l}\text { Some of the DNA fragments were strain specific and some } \\
\text { could differentiate the multivoltine from the bivoltine strains or } \\
\text { vice versa. }\end{array}$ \\
\hline 4 & {$[50]$} & 13 and 2 & SSR & $\begin{array}{l}\text { Detailed analysis of silkworm strains with microsatellite loci } \\
\text { revealed a number of alleles ranging from } 3 \text { to } 17 \text { with } \\
\text { heterozygosity values of } 0.66-0.90 \text {. Along with strain specific } \\
\text { microsatellite markers, diapause and nondiapause } \\
\text { strain-specific alleles were also identified }\end{array}$ \\
\hline 5 & {$[137]$} & 13 and 2 & ISSR and RAPD & $\begin{array}{l}\text { The highest diversity index was observed for ISSRPCR }(0.957) \\
\text { and the lowest for RAPDs }(0.744) \text {. Differentiated diapause and } \\
\text { nondiapause strains }\end{array}$ \\
\hline 6 & [138] & 31 and 7 & SSR & $\begin{array}{l}\text { The average heterozygosity value for each SSR locus ranged } \\
\text { from } 0 \text { to } 0.60 \text {, and the highest one was } 0.96 \text { (Fl0516 in } 4013 \text { ). } \\
\text { The mean polymorphism index content (PIC) was } 0.66 \text { (range } \\
\text { of } 0.12-0.89 \text { ). SSR markers are an efficient tool for fingerprinting } \\
\text { cultivars and conducting genetic-diversity studies in the } \\
\text { silkworm }\end{array}$ \\
\hline 7 & [139] & 20 and 6 & RAPD & Multivoltine Silkworm has more genetic diverse than bivoltine \\
\hline 8 & {$[51]$} & 12 & SSR & $\begin{array}{l}\text { Within a strain, the individual polymorphism of wild silkworm } \\
\text { was significantly higher in abundance than those of } \\
\text { domesticated silkworm }\end{array}$ \\
\hline 9 & [140] & 5 & RAPD & $\begin{array}{l}\text { The genetic distances between the clusters and within the } \\
\text { clusters estimated } 6 \text { percent variability between the } 4 \text { races and } \\
\text { Nistari. RAPDs are very efficient in the estimation of genetic } \\
\text { diversity in populations that are closely related and acclimatized } \\
\text { to local environmental conditions. }\end{array}$ \\
\hline 10 & {$[52]$} & 29 and 4 & CAP & $\begin{array}{l}\text { Considerable genetic diversity observed. Grouped strains } \\
\text { roughly according to their geographical origin. }\end{array}$ \\
\hline 11 & {$[55]$} & 96 & SSR & $\begin{array}{l}\text { The mean polymorphism index content was } 0.71 \text { (range of } \\
0.299-0.919 \text { ). UPGMA cluster analysis of Nei's genetic distance } \\
\text { grouped silkworm strains based on their origin. }\end{array}$ \\
\hline 12 & [141] & 6 and 2 & AFLP & $\begin{array}{l}\text { Higher degree of genetic similarity within Japanese commercial } \\
\text { lines than the Iranian native strains. The distinct clustering of } \\
\text { these two sets of strains and lines reflects differences of the } \\
\text { geographical origin and morphological, qualitative, and } \\
\text { quantitative traits associated with them. }\end{array}$ \\
\hline 13 & {$[61]$} & 7 and 2 & AFLP & $\begin{array}{l}\text { The genetic similarity estimated within and among silkworms } \\
\text { could be explained by the pedigrees, historical and geographical } \\
\text { distribution of the strains, effective population size, inbreeding } \\
\text { rate, selection intensity, and gene flow. }\end{array}$ \\
\hline 14 & {$[64]$} & 6 & RAPD & $\begin{array}{l}\text { The genetic diversity in studying strains was moderately low. } \\
\text { Estimates of gene diversity in populations were higher in total } \\
(\mathrm{Ht}) \text { as compared to those within population diversity (Hs). }\end{array}$ \\
\hline 15 & [142] & 20 and 6 & ISSR & $\begin{array}{l}\text { In selected mutant genetic stocks, the average number of } \\
\text { observed alleles was }(1.7080 \pm 0.4567) \text {, effective alleles } \\
(1.5194 \pm 0.3950) \text {, and genetic diversity }(\mathrm{Ht})(0.2901 \pm 0.0415) \text {. } \\
\text { ISSR is a valuable method for determining the genetic } \\
\text { variability among mutant silkworm strains. }\end{array}$ \\
\hline
\end{tabular}


TABle 3: Continued.

\begin{tabular}{|c|c|c|c|c|}
\hline $\begin{array}{l}\text { Sl } \\
\text { number }\end{array}$ & $\begin{array}{l}\text { Reference } \\
\text { number }\end{array}$ & $\begin{array}{c}\text { Number of } \\
\text { genotypes and } \\
\text { Cluster }\end{array}$ & $\begin{array}{l}\text { Measures of } \\
\text { genetic diversity }\end{array}$ & Conclusion \\
\hline 16 & {$[63]$} & 25 and 3 & Intronic sequences & $\begin{array}{l}\text { The degree of sequence divergence in some introns is very } \\
\text { variable, suggesting the potential of using intronic sequences for } \\
\text { strain identification. }\end{array}$ \\
\hline 17 & {$[58]$} & 12 & $\begin{array}{l}\text { RAPD, ISSR, and } \\
\text { RFLP-STS }\end{array}$ & $\begin{array}{l}\text { RAPD generated } 93.6 \% \text {, ISSR was } 84.62 \text {, and RFLP was } 75.6 \% \\
\text { polymorphism. Ability to discriminate bivoltine and } \\
\text { multivoltine. }\end{array}$ \\
\hline 18 & [143] & 3 and 2 & RAPD & $\begin{array}{l}\text { The diversity within the populations (Hs) was } 0.1334 \text { and the } \\
\text { magnitude of differentiation among the populations (GST) was } \\
0.2968 \text {. }\end{array}$ \\
\hline 19 & {$[56]$} & 14 & ISSR & $\begin{array}{l}\text { ISSR markers has generated } 92 \text { percent were } \\
\text { polymorphic,diapausing and non-diapausing silkworm stocks } \\
\text { could be distinguished by specific marker. }\end{array}$ \\
\hline 20 & {$[144]$} & 8 and 2 & $\begin{array}{l}\text { ISSR, RAPD, and } \\
\text { isozymes }\end{array}$ & Sufficient polymorphism and genetic diversity observed. \\
\hline 21 & [145] & 30 and 2 & ISSR & $\begin{array}{l}\text { PCA analysis helped to visualize the two major clusters which } \\
\text { included the multivoltines and bivoltines separately. The } \\
\text { grouping of bivoltines in the PCA analysis clearly showed higher } \\
\text { similarity among bivoltines as compared to the multivoltines. }\end{array}$ \\
\hline 22 & {$[62]$} & 13 and 2 & SSR and $\mathrm{mtDNA}$ & $\begin{array}{l}\text { The heterozygosity generated by the seven pairs of SSR primers } \\
\text { varied from } 0.098 \text { to } 0.396 \text {. Considerable genetic diversity is } \\
\text { present among the } 13 \text { silkworm genotypes. }\end{array}$ \\
\hline 23 & {$[146]$} & 30 and 2 & ISSR & $\begin{array}{l}\text { The grouping of bivoltines in the PCA analysis clearly showed } \\
\text { higher similarity among bivoltines as compared to the } \\
\text { multivoltines. }\end{array}$ \\
\hline 24 & {$[66]$} & $\begin{array}{l}\text { A. Pernyi-3 } \\
\text { S. cynthia ricini-12 } \\
\text { B. mori-12 }\end{array}$ & RAPD & $\begin{array}{l}\text { At the species level, } A \text {. pernyi and B. mori showed high levels of } \\
\text { genetic diversity, whereas S. cynthia ricini showed low level of } \\
\text { genetic diversity. However, at the strain level, A. pernyi had } \\
\text { relatively the highest genetic diversity and B. mori had the } \\
\text { lowest genetic diversity. }\end{array}$ \\
\hline 25 & [147] & 14 and 2 & RAPD, ISSR & $\begin{array}{l}\text { High polymorphisms (70.91 and } 74.70 \% \text { ) were revealed by ISSR } \\
\text { and RAPD markers. }\end{array}$ \\
\hline 26 & {$[59]$} & 4 and 2 & RAPD & $\begin{array}{l}\text { Multivoltine silkworm races are genetically more distant than } \\
\text { the two bivoltine silkworm. Genetic distances among the } \\
\text { multivoltine and bivoltine silkworm were } 0.52 \text { and } 0.27 \text {, } \\
\text { respectively. }\end{array}$ \\
\hline 27 & {$[60]$} & 9 and 3 & RAPD & $\begin{array}{l}\text { The average genetic distance between the samples was } 0.53 \text {. The } \\
\text { average genetic distance from analyzed samples proved to be } \\
\text { relatively high. }\end{array}$ \\
\hline 28 & {$[148]$} & 8 and 6 & RAPD & $\begin{array}{l}\text { Genetic distances varied from } 0.28889 \text { (B75.2-C1.4) to } 0.92437 \\
\text { (A1.2-A1.3) with an average of } 0.58497 \text {. Silkworms group a high } \\
\text { genetic diversity. }\end{array}$ \\
\hline 29 & {$[65]$} & 5 and 2 & ISSR & $\begin{array}{l}\text { Artificial selection during seven continuous generations } \\
\text { generally caused lesser genetic distance between the breeds. }\end{array}$ \\
\hline & [149] & 6 and 3 & ISSR & $\begin{array}{l}\text { This marker could not discriminate same geographical races } \\
\text { correctly. }\end{array}$ \\
\hline 30 & {$[150]$} & 10 and 3 & RAPD & $\begin{array}{l}\text { The genotypes were grouped based on voltinism and bivoltines } \\
\text { are subgrouped based on silk productivity nature of silkworm } \\
\text { breeds. }\end{array}$ \\
\hline 31 & {$[151]$} & 10 & SSR & $\begin{array}{l}\text { Sufficient polymorphism and genetic diversity observed. The } \\
\text { genotypes were grouped based on voltinism and subdivided } \\
\text { based on cocoon shape and cocoon colour. }\end{array}$ \\
\hline
\end{tabular}


the amount and distribution of genetic variation in crop genomes as compared to their wild progenitors in maize [69].

5.1. Domestication. Over the past 12000 years, humans have sampled, selected, cultivated, travelled through, and colonized new environments, thus inducing a plethora of bottlenecks, drifts, and selection. Plant breeders have accelerated the whole process by selecting preferred genotypes [46]. In the broadest sense, alteration and narrowing of crop genetic diversity began with the first domestication of wild plants/animals. Domestication represents a relatively recent evolutionary event, occurring over the past 13,000 years after the Neolithic revolution [70,71]. This process frequently leads to the improvement of economically important traits and the diversification of morphological traits in domesticated species compared to their wild ancestors. Silkworm domestication, which is a relatively recent evolutionary event, may have generated a large number of alterations and diversification in the structure of an evolutionarily conserved morphogenetic gene [72]. There is an assumption that the process of domestication and selection has resulted in drastic narrowing of the genetic variation and homozygosity in mulberry silkworm which has been domesticated over 5000 years ago. Xia et al. [73] compared the whole genome sequencing of $29 \mathrm{~B}$. mori strains and 11 Chinese $B$. mandarina individuals by 1.50 billion short reads and concluded that $B$. mori was clearly genetically differentiated from $B$. mandarina. At the same time, based on the high level of conservation of genetic variability, the authors estimated that a large number of $B$. mandarina individuals were used for domestication (i.e., the population bottleneck during silkworm domestication might not have been severe.) Therefore, gene flow limited to $B$. mori could have occurred for many genes during silkworm domestication. Recently, Yu et al. [74] and Guo et al. [75] reported decreased level of genetic variation in $B$. mori genes or regions compared to those in Chinese B. mandarina in the domestication targeted gene. About $40.7 \%$ or $49.2 \%$ of the genetic diversity of wild silkworm was lost in domesticated silkworm [74]. Study conducted with B. Mandarina and B. mori by Guo et al. [75] reveals that diversity of $B$. mori is significantly lower than that of $B$. mandarina. Further gene DefA showed signature of artificial selection by all analysis methods and might experience strong artificial selection in $B$. mori during domestication resulting less diversity [75]. However, when analysing the carotenoid binding protein (CBP) genes in $B$. mori identified large copy number variations and retrotransposon associated structural differences in CBP from $B$. mori, which were absent from $B$. mandarina, and concluded that domestication can generate significant diversity of gene copy number and structure over a relatively short evolutionary time.

5.2. Breeding Too Causes Loss of Variability. Breeding systems and life history traits govern the transmission of genes between generations and have been long recognized as impacting the genetic diversity and population genetic structure [76-78]. Breeding is a strong force in the reduction of genetic diversity [79] and views the introduction of modern varieties as evidence of genetic erosion [80]. Silkworm breeding by definition is the selection of superior genotypes and/or phenotypes over a period of time. During the last decades, development and increased focus on more efficient selection programmes have accelerated genetic improvement in a number of breeds. As a result, highly productive silkworm breeds have replaced local ones across the world [81-84]. This development has led to growing concerns about the erosion of genetic resources. As the genetic diversity of low-production breeds is likely to contribute to current or future traits of interest $[85,86]$, they are considered essential for maintaining future breeding options.

Selection naturally results in a narrowing of the genetic base of the genotype. Even if the breeder has introduced alleles from indigenous races to his target genotype, he/she must then begin the process of "weeding out" the alleles that are undesirable. This weeding out of undesirable alleles is once again narrowing the genetic base of the line. Practically, a breeder typically uses the best genotypes available and selects superior progeny. The continual use of the best genotypes as parents naturally narrows the gene pool to only those alleles that are available from the elite parents and therefore tends to decrease the genetic variation of the population [87]. There is also a threat or loss of genetic diversity as a result of replacement of wild species by exotic high-yielding varieties. Typically, population size is also a major source of loss of genetic diversity.

5.3. Effects of Selection on Diversity. Patterns of diversity in any populations are likely to be affected by selection. Balancing selection due to overdominance (heterozygote advantage), or to frequency dependent selection, may maintain variants in populations, and environmental differences may select for different genotypes in different populations [3]. Purifying selection, however, removes deleterious variants that arise by mutation; such variants are expected to be present at frequencies lower than predicted for the neutral equilibrium. Another form of directional selection occurs when advantageous mutations rapidly reach high frequencies whether they spread throughout a species to fixation or just within a population undergoing adaptation to its local environment [88, 89]. Artificial selection has been widely utilized in the breeding programmes concerning B. mori, which is of commercially important insect. Nevertheless, the genetic diversity of silkworm is greatly reduced during systematically extensive selection for a few target traits. In general, selection of superior individuals results in genetic gain, but also loss in genetic diversity and it is strongly dependent on selection method and selection intensity [90]. Selection will have two important consequences: (1) the genetic average value will be changed, thus conventionally it measured a gain, and (2) there will be change in diversity, and this will be measured by relative effective number of families. It is a well-known fact that diversity is affected by directional selection. Directional or disruptive selection will ultimately fix one allele and thereby deplete genetic variation. It has been suggested that directional selection 
decreases the level of developmental precision or developmental stability [91] because it may prevent the evolution of canalisation and possibly favour those mechanisms that increase the phenotypic variation $[92,93]$ showing that systematic selection of parents' results in reduced genetic variation among their offspring. After 4-5 generations with the same selection intensity, the reduction will stabilize. Class example of diversity changes through directional selection and inbreeding in silkworm was reported by Pradeep et al. [94]. They have separated larval populations of Nistari strain based on the shortest larval duration (SLD) and the longest larval duration (LLD) and maintained for 4 more generations. RAPD and ISSR primers generated polymorphic profiles in LLD and SLD lines. Distinct markers specific to LLD individuals were observed from the 3rd generation and indicated selection induced differentiation of allelic variants for longer larval duration. This finding implies that selection combined with inbreeding could result in lines with different genetic properties following separation from the original parental populations. According to Strunnikov [95], continuous selection and inbreeding could have induced a homozygous state of the recessive gene for longer larval duration, where shorter larval duration is the dominant and fitness character. Though it introduced diversity, because of losing its dominant or fitness characters, chances of survival become vulnerable. Further, as reported by Seidavi [96], the genetic performance of selected population of silkworm for cocoon weight trait after the fourth generation shown increased sensitivity towards environment resulting in poor survival due to selection based on productivity traits indicating effect of selection on diversity.

5.4. Genetic Drift. Genetic drift is the chance changes in allele frequency that result from the random sampling of gametes from generation to generation in a finite population. It has the same expected effect on all loci in the genome [97]. In a large population, on the average, only a small chance change in the allele frequency will occur as the result of genetic drift. On the other hand, if the population size is small, then the allele frequency can undergo large fluctuations in different generations in a seemingly unpredictable pattern and can result in chance fixation (going to a frequency of 1.0) or the loss (going to a frequency of 0.0 ) of an allele. A classic illustration of how finite population size affects allele frequency was provided by Buri [98]. He looked at the frequency of two alleles at the brown locus that affects eye color in Drosophila melanogaster in randomly selected populations of size 16 . However around 107 number of populations had 0 to $32 b w^{75}$ genes in different (19) generations. The total number of populations fixed for one of the two alleles increased at nearly a linear rate after generation 4 and in generation 19 it is nearly equal for the two alleles, with 30 populations fixed for $b w$ and 28 fixed for $b w^{75}$. In silkworm germplasm maintenance centers, at every cycle only 40-60 cocoons are selected from each strain/breed for the next generation, from which around 20 layings are prepared and subsequently only 5-6 layings are brushed for next generation. This size of population is small which may be lead to change in allele frequency as explained by Buri [98].
5.5. Effects of Inbreeding. Loss of genetic diversity among populations occurs due to the synergetic effects of inbreeding and environmental stressors [99]. The negative interaction between inbreeding and environmental stress reflects on population growth rates and inbreeding and environmental effects may interact in their effects on population dynamics. Inbreeding is characterized by an increase in homozygosity resulting in increased expression of recessive deleterious alleles (partial dominance hypothesis) [100] and/or reduced opportunity to express heterozygote superiority (overdominance hypothesis) [101]. Selfing has direct genetic consequences, including its effect on the intensity of inbreeding depression [102] and the partitioning of genetic diversity within and among populations [103]. A consequence of inbreeding is that it makes it much more likely that an individual is homozygous for a rare gene because it is more likely that two related parents simultaneously possess a rare allele and transmit it to their inbred offspring than the two unrelated individuals independently transmit the same rare allele to noninbred offspring. Thus inbreeding seems to reduce fitness because it reveals harmful genes in homozygotes [104].

Sericulture practicing countries maintain hundreds of inbred lines of silkworm in germplasm centres for several decades by selection and inbreeding. Sibling mating of the progenies derived from a single brood is preferred for pure stocks so that the original traits of the races are maintained through generations. Generally, breeders try to maintain the original characters of the races/breeds through selection with care to avoid inbreeding depression. However, the effects of inbreeding can accumulate over many generations, as the frequency of slightly deleterious alleles can gradually increase over time due to genetic drift $[105,106]$. This is a particular concern in small populations, where natural selection can be inefficient for alleles that have only slight effects on fitness [107]. The rate at which genetic diversity is lost will depend on the population's size and degree of isolation; small, isolated populations can lose genetic diversity within a few generations, whereas large, continuous populations may not lose significant amounts of diversity over thousands of years [108]. In small populations where genetic drift is most rapid, the fixation of common alleles will result in the reduction of genetic diversity. This phenomenon is applicable in silkworm, as different silkworm strains are maintained with small population leading to genetic drift thereby may be reducing genetic diversity. Further, Li et al. [109] when analysing genetic diversity in B. mandarina and B. mori concluded that the polymorphism level $(\theta \pi)$ of $\mathrm{mt}$ sequence among Chinese wild population $\left(6.20 \times 10^{-3}\right.$ nucleotide differences per site) is more than six times that among domesticated varieties $\left(1.14 \times 10^{-3}\right)$ and pointing out that the relative larger reduction in polymorphism is most likely caused by inbreeding or population bottlenecking.

\section{Broadening the Genetic Diversity}

Continuous breeding and selection of silkworm breed for uniformity narrows genetic diversity. One of the approaches 
to broaden the genetic diversity is the use of recent advances in molecular biology and biotechnology, which allow the transfer of specific genes from diverse sources to target genotypes. In [110], through transgenic approach, by gene addition, subtraction, and pathway redirection, the genetic constituents of crops can be modified and broadened, resulting in new and improved traits. Another approach of broadening the genetic diversity is by the use of exotic germplasm [111]. It will create genotypes with a diverse range of desirable characteristics. The genetic variation that breeders need to introduce these characteristics is often available only through the exchange of genetic resources. This exchange is necessary because some areas of the world have richer resources of genetic diversity, which will be useful in creation of variation.

\section{Germplasm Conservation}

Conservation of genetic diversity is essential to the longterm survival of any species, particularly in light of changing environmental conditions. Reduced genetic diversity may negatively impact the adaptive potential for a species. Increasing population size and maximizing genetic diversity are among the primary goals of conservation management [112]. The silkworm germplasm maintenance centres generally follow brushing of "composite population" type of all strains to avoid inbreeding depression as well as genetic erosion and maintain the gene pool as far as possible. Composite laying is defined as collection of a known number of eggs from a known number of individual laying sources that represents the whole population. Though composite layings method can retain gene pool, there is a concern regarding populations, as even slight selection has a drastic effect on genetic variability when the effective population size $\mathrm{N}$ is large [113]. In this method, only 250-500 larvae are retained in a strain; improper selection can lead to inbreeding depression and natural selection can be inefficient for alleles that have only slight effects on fitness [107].

\section{Strategies Required for Conservation of Silkworm Genetic Resources}

(1) The curator of the germplasm bank should carefully verify the available genetic resources and avoid duplicates before collection and introduction of new material.

(2) Development of cost-effective, viable, and costeconomic conservation practices through modification or development of long-term preservation of silkworm genetic resources to reduce the number of crop cycles is required.

(3) Conservation through modern methods includes cryopreservation of sperm, artificial insemination, and induction of synthetic diapause hormones to be explored.

(4) Genetic resources should be categorized as most sensitive and sensitive based on their availability in one place or in more than one place, respectively.
(5) The most sensitive genetic resources should be conserved in more than one place by establishing backup stations under the control of main germplasm station.

(6) Establishment of centers for preservation of endangered/local species under in situ condition is required.

(7) Use of silkworm genetic resources for nonsericultural use other than cocoon production needs importance.

\section{Conclusion}

Though silkworm has been domesticated for hundreds of generations, based on available literature, it is speculated that it has not experienced any major reduction of genetic diversity due to phenotypic selection and breeding. But there is concern that bottlenecks may restrict breeding flexibility and slow response to new opportunities, pests, pathogens, and other practices in the future. To broaden the gene pool of silkworm, exotic elite strains were required to be introduced from various countries. The genomes of introduced exotic germplasm will broaden the gene pool; thereby diversity can be maintained. The original genetic composition of genetic resources should be maintained by avoiding genetic drift and selection process. Maintaining adequate population size can prevent the loss of genetic variability due to genetic drift [114]. Study on effects of inbreeding on inbreeding coefficients in silkworm populations is limited. Hence understanding the effects of inbreeding for various traits can be very crucial points in the management of germplasm. As suggested by Doreswamy and Subramanya Gopal [115] during stock maintenance in germplasm centers, rigid selection for more numbers of generations is required to retain original characteristics of the inbred lines and also reduces the deleterious effects of inbreeding.

\section{Conflict of Interests}

The authors declare that there is no conflict of interests regarding the publication of this paper.

\section{References}

[1] J. Nagaraju and M. R. Goldsmith, "Silkworm genomicsprogress and prospects," Current Science, vol. 83, no. 4, pp. 415425, 2002.

[2] Y. Banno, T. Shimada, Z. Kajiura, and H. Sezutsu, "The silkworm-an attractive bioresource supplied by Japan," Experimental Animals, vol. 59, no. 2, pp. 139-146, 2010.

[3] D. Charlesworth and T. R. Meagher, "Effects of inbreeding on the genetic diversity of populations," Philosophical Transactions of the Royal Society B: Biological Sciences, vol. 358, no. 1434, pp. 1051-1070, 2003.

[4] W. L. Brown, "Genetic diversity and genetic vulnerability-an appraisal,” Economic Botany, vol. 37, no. 1, pp. 4-12, 1983.

[5] V. R. Rao and T. Hodgkin, "Genetic diversity and conservation and utilization of plant genetic resources," Plant Cell, Tissue and Organ Culture, vol. 68, no. 1, pp. 1-19, 2002.

[6] I. A. Matus and P. M. Hayes, "Genetic diversity in three groups of barley germplasm assessed by simple sequence repeats," Genome, vol. 45, no. 6, pp. 1095-1106, 2002. 
[7] S. A. Mohammadi and B. M. Prasanna, "Analysis of genetic diversity in crop plants-salient statistical tools and considerations," Crop Science, vol. 43, no. 4, pp. 1235-1248, 2003.

[8] A. A. Jaradat, M. Shahid, and A. Al-Maskri, "Genetic diversity in the Batini barley landrace from Oman: II. Response to salinity stress," Crop Science, vol. 44, no. 3, pp. 997-1007, 2004.

[9] Z. Ahmad, S. U. Ajmal, M. Munir, M. Zubair, and M. S. Masood, "Genetic diversity for morpho-genetic traits in barley germplasm," Pakistan Journal of Botany, vol. 40, no. 3, pp. 12171224, 2008.

[10] M. R. Goldsmith, "Recent progress in silkworm genetics and genomics," in Molecular Biology and Genetics of the Lepidoptera, M. R. Goldsmith and F. Marec, Eds., pp. 25-48, CRC, Boca Raton, Fla, USA, 2009.

[11] P. C. Mahalanobis, "On the generalized distance in statistics," Proceedings of National Academy of Sciences, India, vol. 2, no. 1, pp. 49-55, 1936.

[12] C. R. Rao, Advanced Statistical Methods in Biometrical Research, John Wiley and Sons, New York, NY, USA, 1952.

[13] M. S. Jolly, R. K. Datta, M. K. R. Noamani et al., "Studies on genetic divergence in mulberry silkworm Bombyx mori L," Sericologia, vol. 29, no. 4, pp. 545-553, 1989.

[14] G. Subba Rao, S. K. Das, and N. K. Das, "Genetic divergence among fifteen multivoltine genetic stocks of silkworm (Bombyx mori L.)," Indian Journal of Sericulture, vol. 30, no. 1, pp. 72-74, 1991.

[15] R. Govindan, S. Rangaiah, T. K. Narayana Swamy, M. C. Devaiah, and R. S. Kulkarni, "Genetic divergence among multivoltine genotypes of silkworm (Bombyx mori L.)," Environmental Ecology, vol. 14, no. 4, pp. 757-759, 1996.

[16] N. B. Pal, S. M. Moorthy, M. Z. Khan, N. K. Das, and K. Mandal, "Analysis of genetic diversity in some multivoltine silkworm genotypes of Bombyx mori L," in Proceedings of the Golden Jubilee National Conference on Sericulture Innovations: Before and Beyond, Abstract, p. 68, CSRTI, Mysore, India, January 2010.

[17] K. Mandal, S. M. Moorthy, S. Sen, N. K. Das, and C. R. Sahu, "An analysis of genetic variation and diversity in bivoltine silkworm (Bombyx mori L.) genotypes," in Proceedings of the National Symposium on Deccan Biodiversity Co-Existance of Funal Species in Changing Landscapes, Abstract, p. 38, Osmania University, Hyderabad, December 2010.

[18] P. Mukherjee, S. Mukherjee, and P. Kumaresan, "An analysis of genetic divergence in Indian multivoltine silkworm (Bombyx mori L.) germplasm," Sericologia, vol. 39, no. 3, pp. 337-347, 1999.

[19] N. B. Pal and S. M. Moorthy, "Assessment of variability in larval and cocoon traits in some genotypes of bivoltine silkworm, Bombyx mori L," International Journal of Research in Biological Sciences, vol. 1, no. 4, pp. 59-65, 2011.

[20] S. K. Sen, B. P. Nair, S. K. Das et al., "Relationship between the degree of heterosis and genetic divergence in the silkworm, Bombyx mori L," Sericologia, vol. 36, no. 2, pp. 215-225, 1996.

[21] P. Kumaresan, T. S. Mahadevamurthy, K. Thangavelu, and R. K. Sinha, "Further studies on the genetic divergence of multivoltine silkworm (Bombyx mori L.) genotypes based on economic characters," Entomon, vol. 28, no. 3, pp. 193-198, 2003.

[22] B. Mohan, N. Balachandran, M. Muthulakshmi et al., "Stratification of silkworm (Bombyx mori L.) germplasm for establishing core-set using characterisation data," International Journal of Tropical Agricultur, vol. 29, no. 3-4, pp. 325-329, 2011.
[23] G. Subba Rao, S. K. Das, N. K. Das, and S. Nandi, "Genetic divergence among bivoltine races of silkworm (Bombyx mori)," Indian Journal of Agricultural Sciences, vol. 59, no. 12, pp. 761765, 1989.

[24] M. Farooq and H. P. Puttaraju, "Genetic divergence in bivoltine silkworm Bombyx mori L," in Proceedings of the National Seminar on Mulberry Sericulture Research in India, Abstract, p. 170, KSSRDI, Bangalore, India, November 2001.

[25] A. R. Hughes, B. D. Inouye, M. T. J. Johnson, N. Underwood, and M. Vellend, "Ecological consequences of genetic diversity," Ecology Letters, vol. 11, no. 6, pp. 609-623, 2008.

[26] N. Mittal and A. K. Dubey, "Microsatellite markers-a new practice of DNA based markers in molecular genetics," Pharmacognosy Reviews, vol. 3, no. 6, pp. 235-246, 2008.

[27] B. L. Fisher and M. A. Smith, "A revision of Malagasy species of Anochetus mayr and Odontomachus latreille (hymenoptera: formicidae)," PLoS ONE, vol. 3, no. 5, Article ID e1787, 2008.

[28] B. J. McGill, B. J. Enquist, E. Weiher, and M. Westoby, "Rebuilding community ecology from functional traits," Trends in Ecology and Evolution, vol. 21, no. 4, pp. 178-185, 2006.

[29] R. J. Parkash, P. Yadav, and M. Vashisht, "Allozymic variation at $\mathrm{ADH}$ locus in some Drosophila species," Perspectives in Cytology and Genetics, vol. 8, pp. 495-502, 1992.

[30] N. Yoshitake and M. Eguchi, "Distribution of blood esterase types in various strains of the silkworm, Bombyx mori L," Japan Journal of Sericulture, vol. 34, pp. 95-98, 1965 (Japanese).

[31] N. Yoshitake and M. Akiyama, "Genetic aspect on the esterase activities of the egg in the silkworm Bombyx mori L," Japan Journal of Sericulture, vol. 34, pp. 327-332, 1965 (Japanese).

[32] M. Eguchi, N. Yoshitake, and H. Kai, "Types and inheritance of blood esterase in the silkworm, Bombyx mori L," Japan Journal of Genetics, vol. 40, pp. 15-19, 1965.

[33] M. Eguchi and N. Yoshitake, "Interrelation of non specific esterase among various tissues in the silkworm, Bombyx mori L," Japan Journal of Sericulture, vol. 36, pp. 193-198, 1967.

[34] M. Eguchi, Y. Takahama, M. Ikeda, and S. Horii, "A novel variant of acid phosphatase isozyme from hemolymph of the silkworm, Bombyx mori," Japan Journal of Genetics, vol. 63, no. 2, pp. 149157, 1988.

[35] A. Shabalina, "Esterase genetic polymorphism in haemolymph of larvae Bombyx mori," Comptes Rendus de l'Academie Bulgare des Sciences, vol. 43, pp. 105-110, 1990.

[36] P. Somasundaram, K. Ashok kumar, K. Thangavelu, P. K. Kar, and R. K. Sinha, "Preliminary study on isozyme variation in silkworm germplasm of Bombyx mori (L.) and its implication for conservation," Pertanika Journal of Tropical Agricultural Science, vol. 27, no. 2, pp. 163-171, 2004.

[37] S. M. Moorthy, S. K. Das, P. R. T. Rao, S. Raje Urs, and A. Sarkar, "Evaluation and selection of potential parents based on selection indices and isozyme variability in silkworm, Bombyx mori L," Internatioanl Journal of Industrial Entomology, vol. 14, pp. 1-7, 2007.

[38] T. Staykova and D. Grekov, "Stage specificity and polymorphism of haemolymph esterases in races and hybrids of silkworm (Bombyx mori L.) kept in Bulgaria," in Proceedings of the International Workshop on Silk Handcrafts Cottage Industries and Silk Enterprises Development in Africa, Europe, Central Asia and the Near East, \& 2nd Executive Meeting of Black, Caspian seas and Central Asia Silk Association (BACSA), pp. 667-674, Bursa, Turkey, March 2006. 
[39] T. Staykova, "Genetically-determined polymorphism of nonspecific esterases and phosphoglucomutase in eight introduced breeds of the silkworm, Bombyx mori, raised in Bulgaria," Journal of Insect Science, vol. 8, article 18, 2008.

[40] K. Ashok Kumar, P. Somasundaram, A. V. Bhaskara Rao, P. Vara Prasad, C. K. Kamble, and S. Smitha, "Genetic diversity and enzymes among selected silkworm races of Bombyx mori (L.)," International Journal of Science and Nature, vol. 2, no. 4, pp. 773777, 2011.

[41] B. B. Patnaik, T. Datta, A. K. Saha, and M. K. Majumdhar, "Isozymic variations in specific and nonspecific esterase and its thermostability in silkworm, Bombyx mori L," Journal of Environmental Biology, vol. 33, pp. 837-842, 2012.

[42] L. Ronqui, M. Aparecida, and M. C. C. Ruvolo Takasusuk, "Genetic analysis of isoenzymes polymorphisms in silkworm (Bombyx mori L.) strains," Acta Scientiarum Biological Sciences, vol. 35, no. 2, pp. 249-254, 2013.

[43] T. Staykova, E. Ivanova, D. Grekov, and K. Avramova, "Genetic variability in silkworm (Bombyx mori L.) strains with different origin," Acta Zoologica Bulgarica, vol. 4, pp. 89-94, 2012.

[44] T. Staykova, E. N. Ivanova, P. Zenov, Y. VaSileva, D. Arkova Pantaleeva, and Z. Petkov, "Acid phosphatase as a marker for differentiation of silkworm (Bombyx mori) strains," Biotechnology and Biotechnological Equipment, vol. 24, no. 2, pp. 379-384, 2010.

[45] N. Yoshitake, M. Eguchi, and A. Akiyama, "Genetic control of esterase and acid phatase in the silkworm," Journal of Sericulture Science in Japan, vol. 35, pp. 1-6, 1966.

[46] J. Glaszmann, B. Kilian, H. Upadhyaya, and R. Varshney, "Accessing genetic diversity for crop improvement," Current Opinion in Plant Biology, vol. 13, no. 2, pp. 167-173, 2010.

[47] S. A. Wani, M. A. Bhat, Z. Buhroo, M. A. Ganai, and N. Majid, "Role of molecular markers in silkworm improvement," International Journal of Recent Scientific Research, vol. 4, no. 5, pp. 515-523, 2013.

[48] G. M. Nagaraja and J. Nagaraju, "Genome fingerprinting of the silkworm, Bombyx mori, using random arbitrary primers," Electrophoresis, vol. 16, no. 9, pp. 1633-1638, 1995.

[49] N. Thanananta, P. Saksoong, and S. Peyachoknagul, "RAPD technique in silkworm (Bombyx mori): strain differentiation and identification," Thammasat International Journal of Science and Technology, vol. 2, no. 2, pp. 47-51, 1997.

[50] K. D. Reddy, J. Nagaraju, and E. G. Abraham, "Genetic characterization of the silkworm Bombyx mori by simple sequence repeat (SSR)-anchored PCR," Heredity, vol. 83, no. 6, pp. 681687, 1999.

[51] L. Zhang, Y. Huang, X. Miao, M. Qian, and C. Lu, "Microsatellite markers application on domesticated silkworm and wild silkworm," Insect Science, vol. 12, no. 6, pp. 413-419, 2005.

[52] J. H. Huang, S. H. Jia, Y. Zhang et al., "The polymorphism of silkworm, Bombyx mori (L.) amylase gene," Scientia Agricultura Sinica, vol. 39, no. 11, pp. 2390-2394, 2006.

[53] M. Li, C. Hou, X. Miao, A. Xu, and Y. Huang, "Analyzing genetic relationships in Bombyx mori using intersimple sequence repeat amplification," Journal of Economic Entomology, vol. 100, no. 1, pp. 202-208, 2007.

[54] S. B. Dalirsefat and S. Z. Mirhoseini, "Assessing genetic diversity in Iranian native silk-worm (Bombyx mori) strains and Japanese commercial lines using AFLP markers," Iran Journal of Biotechnology, vol. 5, no. 1, pp. 54-63, 2007.
[55] C. X. Hou, M. W. Li, Y. H. Zhang et al., "Analysis of SSR fingerprints in introduced silkworm germplasm resources," Agricultural Sciences in China, vol. 6, no. 5, pp. 620-627, 2007.

[56] F. Malik, H. P. Puttaraju, and S. N. Chatterjee, "Assessment of genetic diversity and association of PCR anchored ISSR markers with yield traits in silkworm, Bombyx mori," Sericologia, vol. 49, no. 1, pp. 1-13, 2009.

[57] J. G. Nagaraju and L. Singh, "Assessment of genetic diversity by DNA profiling and its significance in silkworm, Bombyx mori," Electrophoresis, vol. 18, no. 9, pp. 1676-1681, 1997.

[58] A. K. Awasthi, P. K. Kar, P. P. Srivastava et al., "Molecular evaluation of bivoltine, polyvoltine and mutant silkworm (Bombyx mori L.) with RAPD, ISSR and RFLP-STS markers," Indian Journal of Biotechnology, vol. 7, no. 2, pp. 188-194, 2008.

[59] E. Talebi, M. Khademi, and G. Subramanya, "RAPD markers for understanding of the genetic variability among the four silkworm races and their hybrids," Middle-East Journal of Scientific Research, vol. 7, no. 5, pp. 789-795, 2011.

[60] E. M. Furdui, L. A. Mărghita, D. Dezmirean, I. F. Pop, C. Coroian, and I. Paşca, "Genetic phylogeny and diversity of some Romanian silkworms based on RAPD technique," Animal Science and Biotechnologies, vol. 44, no. 1, pp. 204-208, 2011.

[61] S. Z. Mirhoseini, S. B. Dalirsefat, and M. Pourkheirandish, "Genetic characterization of iranian native Bombyx mori strains using amplified fragment length polymorphism markers," Journal of Economic Entomology, vol. 100, no. 3, pp. 939-945, 2007.

[62] K. Vijayan, C. V. Nair, and S. Raje Urs, "Assessment of genetic diversity in the tropical mulberry silkworm (Bombyx mori L.) with mtDNA-SSCP and SSR markers," Emirate Journal of Food Agriculture, vol. 22, no. 2, pp. 71-83, 2010.

[63] K. Y. Kim, E. M. Lee, I. H. Lee et al., "Intronic sequences of the silkworm strains of Bombyx mori (Lepidoptera: Bombycidae): high variability and potential for strain identification," European Journal of Entomology, vol. 105, no. 1, pp. 73-80, 2008.

[64] R. I. Tunca, T. Staykova, E. Ivanova, M. Kence, and D. Grekov, "Differentiation of silkworm, Bombyx mori strains measured by RAPD analyses," in Proceedings of the Scientific and Technical Reports of the International Conference on Sericulture Challenges in the 21st Century (Serichal 2007) and the 3rd BACSA Meeting, Abstract, pp. 29-30, Vratza, Bulgaria, September 2007.

[65] T. S. Jagadeesh Kumar, "Molecular dynamics of genomic DNA of silkworm breeds for screening under higher temperature Regimes utilising ISSR-primers," International Journal of Science, Environment and Technology, vol. 2, no. 2, pp. 275-285, 2013.

[66] Y. Liu, L. Qin, Y. Li et al., "Comparative genetic diversity and genetic structure of three chinese silkworm species Bombyx mori L. (Lepidoptera: Bombycidae), Antheraea pernyi guérinmeneville and samia cynthia ricini donovan (Lepidoptera: Saturniidae)," Neotropical Entomology, vol. 39, no. 6, pp. 967976, 2010.

[67] K. Yukuhiro, H. Sezutsu, T. Tamura et al., "Little gene flow between domestic silkmoth Bombyx mori and its wild relative Bombyx mandarina in Japan, and possible artificial selection on the CAD gene of B. mori," Genes Genetics Systemics, vol. 87, pp. 331-340, 2012.

[68] D. S. Falconer and T. F. C. Mackay, Introduction to Quantitative Genetics, Longman, Delhi, India, 1996.

[69] Y. Vigouroux, Y. Matsuoka, and J. Doebley, "Directional evolution for microsatellite size in maize," Molecular Biology and Evolution, vol. 20, no. 9, pp. 1480-1483, 2003. 
[70] J. Diamond, Guns, Germs, and Streel: The Fates of Human Societies, Norton, New York, NY, USA, 1997.

[71] M. D. Purugganan and D. Q. Fuller, "The nature of selection during plant domestication," Nature, vol. 457, no. 7231, pp. 843848, 2009.

[72] T. Sakudoh, T. Nakashima, Y. Kuroki et al., "Diversity in copy number and structure of a silkworm morphogenetic gene as a result of domestication," Genetics, vol. 187, no. 3, pp. 965-976, 2011.

[73] Q. Xia, Y. Guo, Z. Zhang et al., "Complete resequencing of 40 genomes reveals domestication events and genes in silkworm (Bombyx mori)," Science, vol. 326, no. 5951, pp. 433-436, 2009.

[74] H. Yu, Y. Shen, G. Yuan et al., "Evidence of selection at melanin synthesis pathway loci during silkworm domestication," Molecular Biology and Evolution, vol. 28, no. 6, pp. 1785-1799, 2011.

[75] Y. Guo, Y. Shen, W. Sun, H. Kishino, Z. Xiang, and Z. Zhang, "Nucleotide diversity and selection signature in the domesticated silkworm, Bombyx mori, and wild silkworm, Bombyx mandarina," Journal of Insect Science, vol. 11, pp. 155-165, 2011.

[76] M. D. Loveless and J. L. Hamrick, "Ecological determinants of genetic structure in plant populations," Annual Review of Ecology, Evolution, and Systematics, vol. 15, pp. 65-95, 1984.

[77] J. L. Hamrigk and M. J. W. Godt, "Effects of life history traits on genetic diversity in plant species," Philosophical Transactions of the Royal Society B: Biological Sciences, vol. 351, no. 1345, pp. 1291-1298, 1996.

[78] K. E. Holsinger, "Reproductive systems and evolution in vascular plants," Proceedings of the National Academy of Sciences of the United States of America, vol. 97, no. 13, pp. 7037-7042, 2000.

[79] P. Gepts, "Plant genetic resources conservation and utilization: the accomplishments and future of a societal insurance policy," Crop Science, vol. 46, no. 5, pp. 2278-2292, 2006.

[80] E. Bennett, "Wheats of the Mediterranean basin," in Survey of Crop Genetic Resources in Their Centre of Diversity, First Report, O. H. Frankel, Ed., pp. 1-8, FAO-IBP, 1973.

[81] T. Gamo, "Recent concepts and trends in silkworm breeding," Farming Japan, vol. 10, no. 6, pp. 11-22, 1976.

[82] H. Ohi and A. Yamashita, "On the breeding of the silkworm races J137 and C137," Bulletin of Sericulture Experiment Station, vol. 27, pp. 97-139, 1977.

[83] L. L. Ren, L. Mini, and C. Hell, "Stability of double cross hybrid combined with current silkworm varieties for spring and early autumn under normal rearing condition," Acta Serica Sinica, vol. 14, no. 1, pp. 42-44, 1988.

[84] R. K. Datta, H. K. Basavaraja, N. Mal Reddy et al., "Evolution of new productive bivoltine hybrids CSR $2 \times$ CSR 4 and CSR $2 \times$ CSR5," Sericologia, vol. 40, pp. 151-174, 2000.

[85] M. W. Bruford, D. G. Bradley, and G. Luikart, "DNA markers reveal the complexity of livestock domestication," Nature Reviews Genetics, vol. 4, no. 11, pp. 900-910, 2003.

[86] M. A. Toro, J. Fernández, and A. Caballero, "Molecular characterization of breeds and its use in conservation," Livestock Science, vol. 120, no. 3, pp. 174-195, 2009.

[87] A. H. D. Brown, "The genetic diversity of germplasm collections," in Proceedings of the Workshop on the Genetic Evaluation of Plant Genetic Resources, pp. 9-11, Canada Research Branch, Agriculture Canada, Toronto, Canada, 1988.

[88] M. R. Macnair, V. E. Macnair, and B. E. Martin, "Adaptive speciation in Mimulus: an ecological comparison of M. cupriphilus with its presumed progenitor, M. guttatus," New Phytologist, vol. 112, no. 3, pp. 269-279, 1989.
[89] X. Vekemans and C. Lefèbvre, "On the evolution of heavymetal tolerant populations in Armeria maritima: evidence from allozyme variation and reproductive barriers," Journal of Evolutionary Biology, vol. 10, no. 2, pp. 175-191, 2001.

[90] S. R. Whitt, L. M. Wilson, M. I. Tenaillon, B. S. Gaut, and E. S. Buckler, "Genetic diversity and selection in the maize starch pathway," Proceedings of the National Academy of Sciences of the United States of America, vol. 99, no. 20, pp. 12959-12962, 2002.

[91] A. P. Moller and A. Pomiankowski, "Fluctuating asymmetry and sexual selection," Genetica, vol. 89, no. 1-3, pp. 267-279, 1993.

[92] M. G. Bulmer, "The effect of selection on genetic variability," American Nature, vol. 105, pp. 201-211, 1971.

[93] C. Pélabon, M. L. Carlson, T. F. Hansen, N. G. Yoccoz, and W. S. Armbruster, "Consequences of inter-population crosses on developmental stability and canalization of floral traits in Dalechampia scandens (Euphorbiaceae)," Journal of Evolutionary Biology, vol. 17, no. 1, pp. 19-32, 2004.

[94] A. R. Pradeep, S. N. Chatterjee, and C. V. Nair, "Genetic differentiation induced by selection in an inbred population of the silkworm Bombyx mori, revealed by RAPD and ISSR marker systems," Journal of Applied Genetics, vol. 46, no. 3, pp. 291-298, 2005.

[95] V. A. Strunnikov, Control over Reproduction, Sex and Heterosis of the Silkworm, Harwood Academic Publishers, Luxembourg, 1995.

[96] A. Seidavi, "Estimation of genetic parameters and selection effect on genetic and phenotype trends in silkworm commercial pure lines," Asian Journal of Animal and Veterinary Advances, vol. 5, no. 1, pp. 1-12, 2010.

[97] S. Wright, EVolution and the Genetics of Populations. Volume 1: Genetic and Biometric Foundations, University of Chicago Press, Chicago, Ill, USA, 1968.

[98] P. Buri, "Gene frequency in small populations of mutant Drosophila," Evolution, vol. 10, pp. 367-402, 1956.

[99] R. Bijlsma, J. Bundgaard, and A. C. Boerema, "Does inbreeding affect the extinction risk of small populations? Predictions from Drosophila," Journal of Evolutionary Biology, vol. 13, no. 3, pp. 502-514, 2000.

[100] D. H. Reed, "The effects of population size on population viability: from mutation to environmental catastrophes," in Conservation Biology: Evolution in Action, S. P. Carroll and C. W. Fox, Eds., pp. 16-35, Oxford University Press, New York, NY, USA, 2008 .

[101] D. Charlesworth and B. Charlesworth, "Quantitative genetics in plants: the effect of the brreeding system on genetic variability," Evolution, vol. 49, no. 5, pp. 911-920, 1995.

[102] D. Charlesworth, B. Charlesworth, and C. Strobeck, "Selection for recombination in self-fertilising species," Genetics, vol. 93, pp. 237-244, 1979.

[103] J. L. Hamrick and M. J. Godt, "Allozyme diversity in plant species," in Plant Population Genetics, Breeding, and Genetic Resources, A. H. D. Brown, M. T. Clegg, A. L. Kahler, and B. S. Weir, Eds., pp. 43-63, Sinauer, Sunderland, Mass, USA, 1990.

[104] R. C. Lacy, "Impacts of inbreeding in natural and captive populations of vertebrates: implications for conservation," Perspectives in Biology and Medicine, vol. 36, no. 3, pp. 480-496, 1993.

[105] R. Lande, "Risk of population extinction from fixation of new deleterious mutations," Evolution, vol. 48, no. 5, pp. 1460-1469, 1994. 
[106] M. C. Whitlock, "Selection, load and inbreeding depression in a large metapopulation," Genetics, vol. 160, no. 3, pp. 1191-1202, 2002.

[107] S. Wright, Evolution and Genetics of Populations. Volume 3: Experimental Results and Evolutionary Deductions, University of Chicago Press, Chicago, Ill, USA, 1977.

[108] K. Zittlau, Population genetic analyses of North American caribou (Rangifer tarandus) [Ph.D. dissertation], Department of Biological Sciences, University of Alberta, Edmonton, Canada, 2004.

[109] D. Li, Y. Guo, H. Shao et al., "Genetic diversity, molecular phylogeny and selection evidence of the silkworm mitochondria implicated by complete resequencing of 41 genomes," BMC Evolutionary Biology, vol. 10, no. 1, article 81, 10 pages, 2010.

[110] M. L. Wang, J. A. Mosjidis, J. B. Morris, Z. B. Chen, N. A. Barkley, and G. A. Pederson, "Evaluation of Lespedeza germplasm genetic diversity and its phylogenetic relationship with the genus Kummerowia," Conservation Genetics, vol. 10, no. 1, pp. 79-85, 2009.

[111] M. Goodman, "Broadening the genetic diversity in maize breeding by use of Exotic germplasm," in The Genetics and Exploitation of Heterosis in Crops, G. Coors and S. Pandey, Eds., pp. 130-149, ASA-CSSA-SSSA, Madison, Wis, USA, 1999.

[112] R. Frankham, J. D. Ballou, and D. A. Briscoe, Introduction to Conservation Genetics, Cambridge University Press, Cambridge, UK, 2002.

[113] W.-H. Li, "Maintenance of genetic variability under the joint effect of mutation, selection and random drift," Genetics, vol. 90, no. 2, pp. 349-383, 1978.

[114] P. S. Guzman and K. R. Lamkey, "Effective population size and genetic variability in the BS11 maize population," Crop Science, vol. 40, no. 2, pp. 338-342, 2000.

[115] J. Doreswamy and S. Gopal, "Inbreeding effects on quantitative traits in random mating and selected populations of the mulberry silkworm, Bombyx mori," Journal of Insect Science, vol. 12, pp. 1-6, 2012.

[116] B. K. Gupta, V. K. Kharoo, and M. Verma, "Genetic divergence in bivoltine strains of silkworm (Bombyx mori L.)," Bioved, vol. 3, no. 2, pp. 143-146, 1992.

[117] T. K. Narayanaswamy, R. Govindan, S. R. Anantha Narayana, and S. Ramesh, "Genetic divergence among some breeds of silkworm Bombyx mori L," Entomon, vol. 27, no. 3, pp. 319-321, 2002.

[118] P. Kumaresan, P. R. Koundinya, S. A. Hiremath, and R. K. Sinha, "An analysis of genetic variation and divergence on silk fibre characteristics of multivoltine silkworm (Bombyx mori L.) genotypes," International Journal of Industrial Entomology, vol. 14, no. 1, pp. 23-32, 2007.

[119] M. Farooq, M. A. Khan, and M. N. Ahmad, "Genetic divergence among bivoltine genotypes of silkworm, Bombyx mori L," in Proceedings of the National Workshop on Seri-Biodiversity Conservation, pp. 94-98, Central Sericultural Germplasm Resources Centre, Hosur, India, March 2009.

[120] M. S. Nezhad, S. Z. Mirhosseini, S. Gharahveysi, M. Mavvajpour, and A. R. Seidavi, "Analysis of genetic divergence for classification of morphological and larval gain characteristics of peanut cocoon silkworm (Bombyx mori L.) germplasm," American-Eurasian Journal of Agriculture and Environmental Sciences, vol. 6, no. 5, pp. 600-608, 2009.

[121] D. B. Zanatta, J. P. Bravo, J. F. Barbosa, R. E. F. Munhoz, and M. A. Fernandez, "Evaluation of economically important traits from sixteen parental strains of the silkworm Bombyx mori L, (Lepidoptera: Bombycidae)," Neotropical Entomology, vol. 38, no. 3, pp. 327-331, 2009.

[122] A. Maqbool and H. U. Dar, "Genetic divergence in some bivoltine silkworm (Bombyx mori L.) breeds,” 2010, http://dspaces .uok.edu.in/jspui//handle/1/1100.

[123] M. Salehi Nezhad, S. Z. Mirhosseini, S. Gharahveysi, M. Mavvajpour, A. R. Seidavi, and M. Naserani, "Genetic diversity and classification of 51 strains of silkworm Bombyx mori (Lepidoptera: Bombycidae) germplasm based on larval phenotypic data using Ward's and UPGMA methods," African Journal of Biotechnology, vol. 9, no. 39, pp. 6594-6600, 2010.

[124] E. Talebi and G. Subramanya, "Genetic distance and heterosis through evaluation index in the silkworm, Bombyx mori (L.)," American Journal of Applied Sciences, vol. 6, no. 12, pp. 1981-1987, 2009.

[125] P. M. Lizardi, "Genetic polymorphism of silk fibroin studied by two-dimensional translation pause fingerprints," Cell, vol.18, no. 2, pp. 581-589, 1979.

[126] T. Egorova, E. Naletova, and Y. Nasirillaev, "Polymorphic system of silkworm haemolymph esterases as a criterion to make programs for parental specimens crossing," Biochemistry of Insects, pp. 54-62, 1985 (Russian).

[127] M. Eguchi, Y. Takahama, M. Ikeda, and S. Horii, "A novel variant of acid phosphatase isozyme from hemolymph of the silkworm, Bombyx mori L," Japanese Journal of Genetics, vol. 63, pp. 149157, 1988.

[128] S. N. Chatterjee and R. K. Datta, "Hierarchical clustering of 54 races and strains of the mulberry silkworm, Bombyx mori L: significance of biochemical parameters," Theoretical and Applied Genetics, vol. 85, no. 4, pp. 394-402, 1992.

[129] S. K. Das, P. K. Chinya, S. Patinaik, S. K. Sen, and G. Subba Rao, "Studies on genetic variability of heamolymph esterases in some genetic stocks of mulberry silkworm Bombyx mori L," Perspectives in Cytology and Genetics, vol. 7, pp. 421-425, 1992.

[130] M. Nei and W. H. LI, "Mathematical model for studying genetic variation in terms of restriction endonucleases," Proceedings of the National Academy of Sciences of the United States of America, vol. 76, no. 10, pp. 5269-5527, 1978.

[131] F. C. Yeh, R. Yang, and T. Boyle, "Population genetic analysis POPGENE version 1.31: Microsoftwindow-based freeware for population genetic analysis," Quick User's Guide, A Joint Project Developed by Centre for International Forestry Research and University of Alberta, Alberta, Canada, 1999.

[132] K. Etebari, S. Z. Mirhoseini, and L. Matindoost, "A study on interspecific biodiversity of eight groups of silkworm (Bombyx mori) by biochemical markers," Insect Science, vol. 12, no. 2, pp. 87-94, 2005.

[133] V. Kumar, S. K. Ashwath, and S. B. Dandin, "Heamolymph protein variability among the silkworm (Bombyx mori) breeds and assessment of their genetic relationship," in Proceedings of the Asia Pacific Congress of Sericulture and Insect Biotechnology (APSERI '06), Abstract, p. 54, Sangju, Republic of Korea, October 2006.

[134] S. Bakkappa and G. Subramanya, "Electrophoretic haemolymph protein pattern in a few bivoltine races of the silkworm, Bombyx mori," The Bioscan, vol. 5, no. 4, pp. 541-544, 2010.

[135] J. Anuradha, S. Somasundaram, S. Vishnupriya, and A. Manjula, "Storage protein-2 as a dependable biochemical index for screening germplasm stocks of the silkworm Bombyx mori (L.)," Albanian Journal of Agriculture Science, vol. 11, pp. 141-148, 2012. 
[136] T. Staykova, "Inter-and intra-population genetic variability of introduced silkworm (Bombyx mori L.) strains raised in Bulgaria," Journal of Biosciences and Biotechnology, vol. 2, no. 1, pp. 73-77, 2003.

[137] J. Nagaraju, K. D. Reddy, G. M. Nagaraja, and B. N. Sethuraman, "Comparison of multilocus RFLPs and PCR-based marker systems for genetic analysis of the silkworm, Bombyx mori," Heredity, vol. 86, no. 5, pp. 588-597, 2001.

[138] M. Li, L. Shen, A. Xu et al., "Genetic diversity among silkworm (Bombyx mori L., Lep., Bombycidae) germplasms revealed by microsatellites," Genome, vol. 48, no. 5, pp. 802-810, 2005.

[139] P. P. Srivastava, K. Vijayan, A. K. Awasthi, P. K. Kar, K. Thangavelu, and B. Saratchandra, "Genetic analysis of silkworms (Bombyx mori) through RAPD markers," Indian Journal of Biotechnology, vol. 4, no. 3, pp. 389-395, 2005.

[140] B. C. K. Murthy, B. M. Prakash, and H. P. Puttaraju, "Fingerprinting of non-diapausing silkworm, Bombyx mori, using random arbitrary primers," Cytologia, vol. 71, no. 4, pp. 331-335, 2006.

[141] S. B. Dalirsefat and S. Z. Mirhoseini, "Assessing genetic diversity in Iranian native silkworm (Bombyx mori L.) strains and Japanese commercial lines using AFLP markers," Iranian Journal of Biotechnology, vol. 5, no. 1, pp. 25-33, 2007.

[142] D. Velu, K. M. Ponnuvel, M. Muthulakshmi, R. K. Sinha, and S. M. H. Qadri, "Analysis of genetic relationship in mutant silkworm strains of Bombyx mori using inter simple sequence repeat (ISSR) markers," Journal of Genetics and Genomics, vol. 35, no. 5, pp. 291-297, 2008.

[143] D. Eroğlu and S. Cakir Arica, "Molecular genetic analysis of three Turkish local silkworm breeds (Bursa Beyazı, Alaca and Hatay Sar1s1) by RAPD-PCR method," Journal of Applied Biological Sciences, vol. 3, no. 2, pp. 17-20, 2009.

[144] K. Ashok Kumar, P. Somasundaram, K. M. Ponnuvel, G. K. Srinivasa Babu, S. M. H. Qadri, and C. K. Kamble, "Identification of genetic variations among silkworm races of Bombyx mori (L.) through bio-molecular tools," Indian Journal of Sericulture, vol. 48, no. 2, pp. 116-125, 2009.

[145] K. Sanjeeva reddy, C. A. Mahalingam, K. A. Murugesh, and S. Mohankumar, "Exploring the genetic variability in Bombyx mori L. with molecular marker," Karnataka Journal of Agricultural Sciences, vol. 22, pp. 479-483, 2009.

[146] K. A. Murugesh, S. Mohankumar, and C. A. Mahalingam, "Molecular marker analysis on genetic variation in domesticated silkworm," Trends in Biosciences, vol. 3, no. 2, pp. 102-105, 2010.

[147] P. P. Srivastava, K. Vijayan, P. K. Kar, and B. Saratchandra, "Diversity and marker association in tropical silkworm breeds of Bombyx mori (Lepidoptera: Bombycidae)," International Journal of Tropical Insect Science, vol. 31, no. 3, pp. 182-191, 2011.

[148] B. Vlaic, L. A. Mărghitaş, A. Vlaic, and P. Raica, "Analysis of genetic diversity of mulberry silkworm (Bombyx mori L.) using RAPD molecular markers," Animal Science and Biotechnologies, vol. 69, no. 1-2, pp. 292-296, 2012.

[149] R. Radjabi, A. Sarafrazi, A. Tarang, K. Kamali, and S. Tirgari, "Intraspecific biodiversity of Iranian local races of silkworm Bombyx mori by ISSR (Inter-Simple Sequence Repeat) molecular marker," World Journal of Zoology, vol. 7, no. 1, pp. 17-22, 2012.

[150] S. M. Moorthy, N. Chandrakanth, S. K. Ashwath, V. Kumar, and B. B. Bindroo, "Genetic diversity analysis using RAPD marker in some silkworm breeds of Bombyx mori L," Annals of Biological Research, vol. 4, no. 12, pp. 82-88, 2013.
[151] N. Chandrakanth, S. M. Moorthy, P. Anusha et al., "Evaluation of genetic diversity in silkworm (Bombyx mori L.) strains using microsatellite markers," International Journal of Biotechnology and Allied Fields, vol. 2, no. 3, pp. 73-93, 2014. 

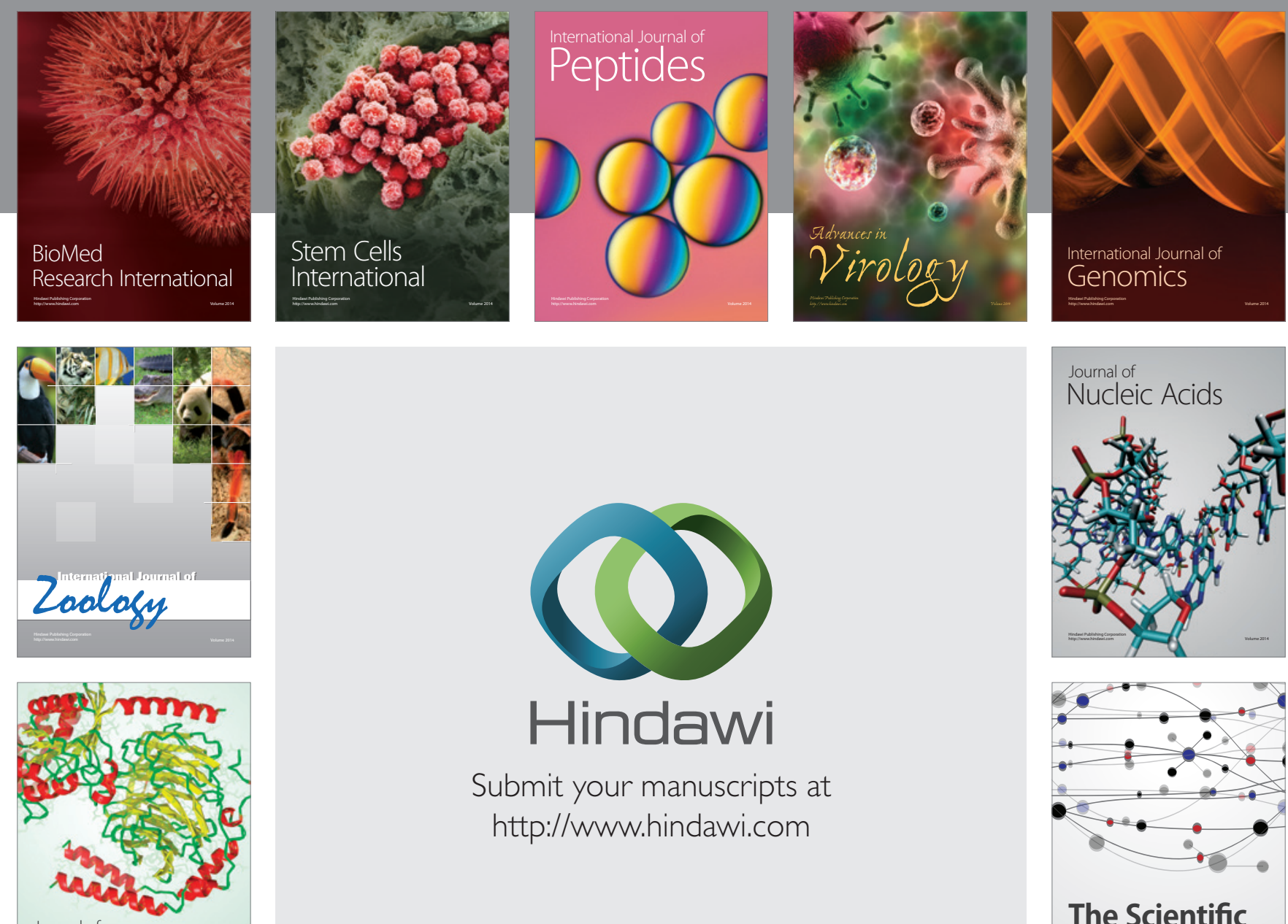

Submit your manuscripts at

http://www.hindawi.com

Journal of
Signal Transduction
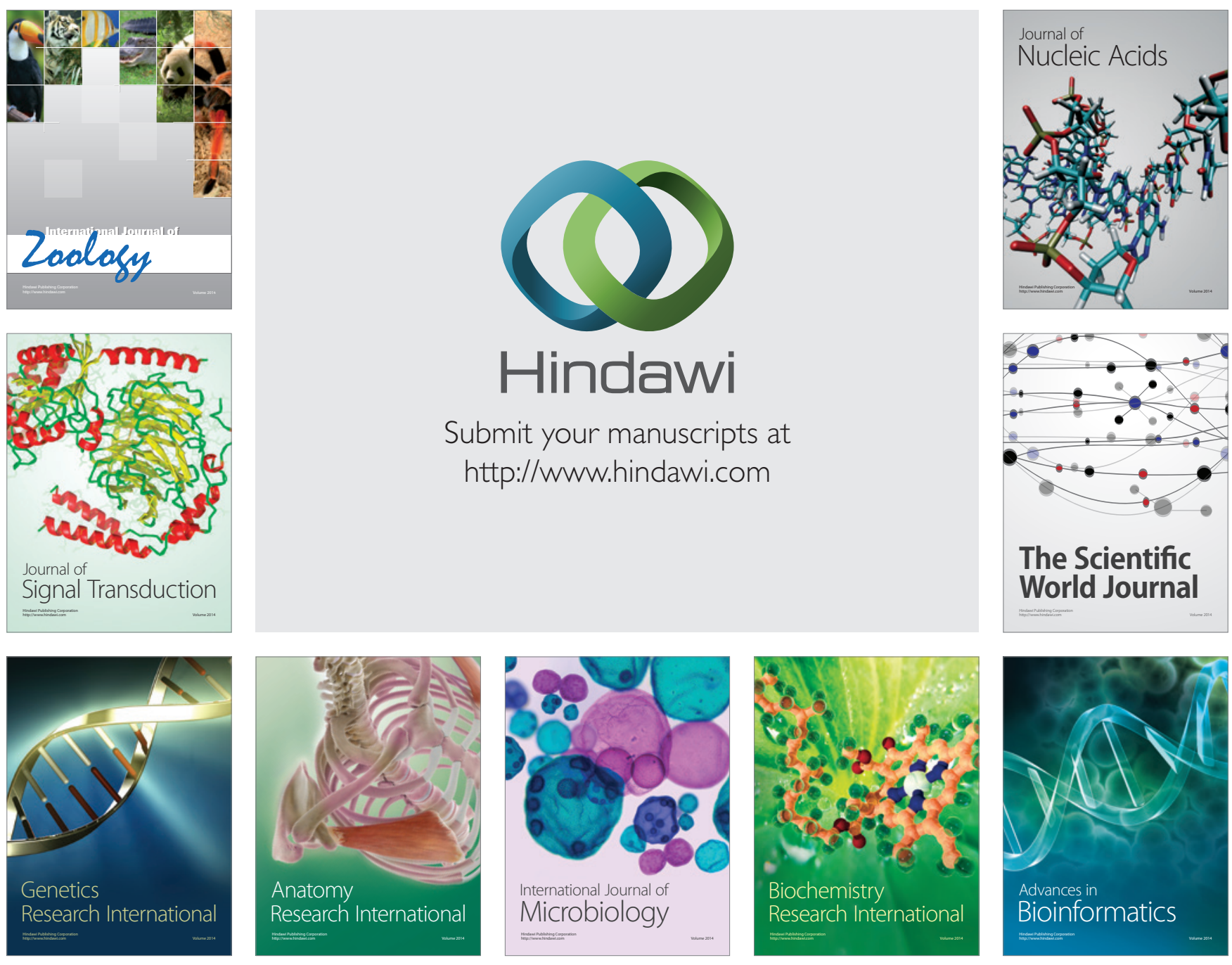

The Scientific World Journal
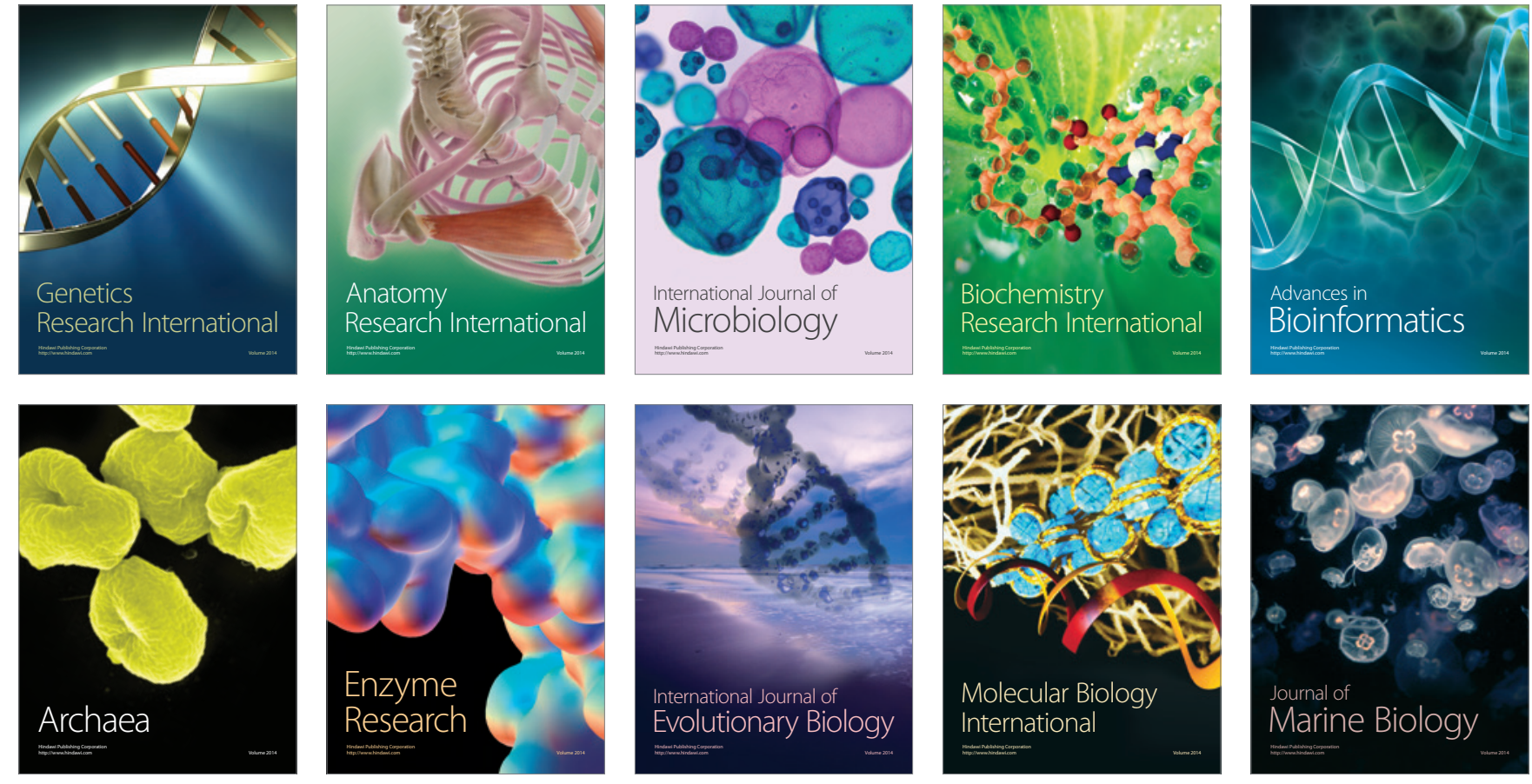